Abstracta Iranica Abstracta Iranica

Revue bibliographique pour le domaine irano-aryen

Volume 28 | 2007

Comptes rendus des publications de 2005

\title{
«Sasanian mint abbreviations: The evidence of style ». NC, 165 2005, pp. 287-299, pls. 38-39.
}

\section{Karin Mosig-Walburg}

\section{(2) OpenEdition}

1 Journals

\section{Édition électronique}

URL : http://journals.openedition.org/abstractairanica/16932

DOI : 10.4000/abstractairanica.16932

ISSN : 1961-960X

Éditeur :

CNRS (UMR 7528 Mondes iraniens et indiens), Éditions de l'IFRI

\section{Édition imprimée}

Date de publication : 15 mai 2007

ISSN : 0240-8910

\section{Référence électronique}

Karin Mosig-Walburg, « «Sasanian mint abbreviations: The evidence of style ». NC, 165 2005, pp.

287-299, pls. 38-39. », Abstracta Iranica [En ligne], Volume 28 | 2007, document 140, mis en ligne le 18 septembre 2007, consulté le 25 septembre 2020. URL : http://journals.openedition.org/ abstractairanica/16932 ; DOI : https://doi.org/10.4000/abstractairanica.16932

Ce document a été généré automatiquement le 25 septembre 2020.

Tous droits réservés 


\title{
« Sasanian mint abbreviations: The evidence of style ». NC, 165 2005, pp. 287-299, pls. 38-39.
}

\author{
Karin Mosig-Walburg
}

L'article est la version écrite d'une conférence présentée lors du "2003 International Numismatic Congress” à Madrid. L'A. traite le problème de l'identification des sigles des ateliers monétaires. On avait déjà tenté auparavant de résoudre ce problème à l'aide des cachets administratifs ou d'autres sources non numismatiques. L'A. propose un approche différente pour arriver à des résultats plus fidèles: l'analyse du style. Il propose des identifications pour les sigles suivants : WH, AS, GW, HL, WYHC.

INDEX

Thèmes : 3.2.3. Séleucides, Parthes et Sassanides

\section{AUTEURS}

KARIN MOSIG-WALBURG

Université de Francfort 